ISSN 0258-7122

Bangladesh J. Agril. Res. 39(3):491-504, September 2014

\title{
EFFECT OF PLANT SPACING AND NITROGEN LEVELS ON NUTRITIONAL QUALITY OF BROCCOLI (Brassica oleracea L.)
}

\author{
M. S. RONI ${ }^{1}$, M. ZAKARIA ${ }^{1}$, M. M. HOSSAIN ${ }^{1}$ AND M. N. SIDDIQUI ${ }^{2}$
}

\begin{abstract}
The study was carried out in the research field and laboratory of the Department of Horticulture, Bangabandhu Sheikh Mujibur Rahman Agricultural University (BSMRAU), Gazipur-1706 during October 2011 to April 2012 to determine optimum level of nitrogen and spacing for improving the nutritional quality of broccoli. There were 15 treatments in the experiment comprising five levels of $\mathrm{N}$ viz., $0,80,120,160$, and $200 \mathrm{~kg} / \mathrm{ha}$ and three plant spacings viz., $60 \mathrm{~cm} \mathrm{x}$ $60 \mathrm{~cm}, 60 \mathrm{~cm} \times 45 \mathrm{~cm}$, and $60 \mathrm{~cm} \times 30 \mathrm{~cm}$. The results revealed that the highest ascorbic acid content $(50.38 \mathrm{mg} / 100 \mathrm{~g})$ was obtained from $\mathrm{S}_{60 \times 30} \mathrm{~N}_{0}$ and the highest $\beta$-carotene content $(50.67 \mathrm{IU} / 100 \mathrm{~g})$ was found in $\mathrm{S}_{60 \times 60} \mathrm{~N}_{0}$. Maximum $\mathrm{Ca}(0.556 \%)$ was found in $\mathrm{S}_{60 \times 60} \mathrm{~N}_{0}$ whereas maximum Fe (159.002 ppm) was in $\mathrm{S}_{60 \times 60} \mathrm{~N}_{200}$. The maximum $\mathrm{P}$ content $(0.081 \%)$ was observed in $\mathrm{S}_{60 \times 60} \mathrm{~N}_{160}$ and maximum $\mathrm{K}$ content $(0.854 \%)$ was found in $\mathrm{S}_{60 \times 45} \mathrm{~N}_{120}$.
\end{abstract}

Keywords: Nitrogen, plant spacing, $\beta$-carotene, ascorbic acid, broccoli, etc.

\section{Introduction}

Broccoli (Brassica oleracea L. var. italica) is one of the non-traditional and relatively new cole crops in Bangladesh. It is a biennial and herbaceous crop belonging to the family Cruciferae. Morphologically, broccoli resembles cauliflower. The terminal curd is rather loose, green in colour and flower stalks are larger than cauliflower. Broccoli originated from west Europe (Prasad and Kumer, 1999) is a very popular vegetable in the United States of America, and very recently Japan has occupied a respectable position in the production of this crop. The crop is also considered as a commercial crop in India (Nonnecke, 1989).

Vegetables play an important role in human nutrition. It provides carbohydrates, fat, minerals, vitamins, and roughages, which constitute the essentials of a balanced diet. But vegetable consumption in Bangladesh is very low and only $80 \mathrm{~g}$ per person per day against the minimum recommended quantity of $220 \mathrm{~g}$ per day (Roy, 2011). The total vegetable production is far below the requirement. In 2009-2010, total vegetable production area was 358148.20 hectares with a production of 2.99 million tons (Anon., 2010). To fulfill the nutritional requirement of people, total production as well as number of vegetables should be increased. Broccoli is a nutritious vegetable than any other

${ }^{1}$ Department of Horticulture, Bangabandhu Sheikh Mujibur Rahman Agricultural University (BSMRAU), Gazipur-1706, ${ }^{2}$ Department of Biochemistry and Molecular Biology, BSMRAU, Gazipur-1706, Bangladesh. 
cole crops (Nieuwhof, 1969). Vitamin C content in fresh broccoli is almost twice that in cauliflower (Lisiewska and Kmiecik, 1969). Per pound of edible portion of broccoli contains protein $9.10 \mathrm{~g}$, fat $0.60 \mathrm{~g}$, carbohydrate $15.20 \mathrm{~g}$, calcium $360.00 \mathrm{mg}$, phosphorus $211.0 \mathrm{mg}$, iron $3.60 \mathrm{mg}$, vitamin-A $970.00 \mathrm{I} . U .$, ascorbic acid $327.00 \mathrm{mg}$, riboflavin $0.59 \mathrm{mg}$ and thiamine $0.26 \mathrm{mg}$ (Thompson and Kelly, 1985). According to analytical data (Appendix II) presented by Thompson and Kelly (1985), broccoli is more nutritious than any other cole crops (cabbage, cauliflower). Devouring broccoli enriched in antioxidants can reduce the risk of some forms of cancer and heart disease. Thus broccoli can play a vital role in improving the nutritional status of the people of Bangladesh. Many people consider this as the most tasteful among the cole crops. Unlike cauliflower, broccoli produces smaller flowering shoots from the leaf axis after the harvest of main apical flower head. Consequently, broccoli may be harvested over a considerable period of time. The stem of broccoli plant, which core is soft and sweet, may also be eaten like vegetable (Sazzad, 1996). As a result, its popularity is increasing day by day in our country. Considering the above points, the present study aimed to investigate the optimum dose of nitrogen and spacing for increasing the nutritional quality of broccoli.

\section{Materials and Method}

The experiment was conducted at the Horticultural Research Farm of Bangabandhu Sheikh Mujibur Rahman Agricultural University (BSMRAU), Gazipur during the period from 10 October 2011 to 21 February 2012 and the nutritive quality analysis was done in the laboratory of the Department of Horticulture, BSMRAU, Gazipur-1706, Bangladesh. The field experiment was laid out in Randomized Complete Block Design with three replications. The whole experimental area was divided into three blocks which represented three replications. The treatments were randomly allotted in each replication. Replication to replication and plot to plot distance were $0.75 \mathrm{~m}$ and $0.5 \mathrm{~m}$, respectively. The size of each unit plot was $2.4 \mathrm{~m} \times 1.8 \mathrm{~m}$. Total number of plots was 45. For nutritive quality analysis of broccoli, the curds were placed in laboratory room. A drying oven (Sanyo, Japan) was used to dry the curd samples for mineral analysis and the laboratory part of the experiment was laid out in Complete Randomized Design with three replications. The experiment consisted of two factors as follows
Factor $-\mathrm{A}$ : Nitrogen levels (5):
a. $\quad \mathrm{N}_{1}=0 \mathrm{~kg} / \mathrm{ha}$
Factor $-\mathrm{B}$ : Plant spacing (3):
b. $\mathrm{N}_{2}=80 \mathrm{~kg} / \mathrm{ha}$
a. $\mathrm{S}_{1}=60 \mathrm{~cm} \mathrm{\times} 60 \mathrm{~cm}$
c. $\mathrm{N}_{3}=120 \mathrm{~kg} / \mathrm{ha}$
b. $\mathrm{S}_{2}=60 \mathrm{~cm} \times 45 \mathrm{~cm}$
d. $\mathrm{N}_{4}=160 \mathrm{~kg} / \mathrm{ha}$
c. $\mathrm{S}_{3}=60 \mathrm{~cm} \mathrm{x} 30 \mathrm{~cm}$
e. $\mathrm{N}_{5}=200 \mathrm{~kg} / \mathrm{ha}$ 
Broccoli (Brassica oleracea var. italica) cv. Premium was used as plant material. The seed was collected from Rajdhani Seed Company, Hannan Mansion (Ground floor), 178, Station road, Seddik Bazer, Dhaka-1000. The seeds were sown in seed bed on 22 October 2011. Proper cares were taken to get normal seedlings. The crop was harvested during 10 January to 30 January 2011. The Broccoli curd was harvested before the buds opened (Thompson and Kelly, 1985).

The harvested curds were used for biochemical analysis. The following data were recorded immediately after harvesting -

i. Water content $(\%)$

ii. Dry matter $(\%)$

iii. Ascorbic acid $(\mathrm{mg} / 100 \mathrm{~g})$

iv. $\quad \beta$-Carotene $(\mathrm{IU} / 100 \mathrm{~g})$

v. Calcium $(\%)$

vi. Iron (ppm)

vii. Potassium $(\%)$

viii. Phosphorus $(\%)$

\section{Water content $(\%)$}

Water content (\%) was determined by using the following formula:

$\%$ Water $=\frac{\text { Fresh weight }- \text { Dry weight }}{\text { Fresh weight }} \times 100$.

\section{Dry matter $(\%)$}

Dry matter (\%) was estimated by using the following formula:

$\%$ Dry matter $=\frac{\text { Dry weight }}{\text { Fresh weight }} \times 100$.

\section{Estimation of ascorbic acid}

Preparation of the extract for the determination of ascorbic acid:

A sample of $50 \mathrm{~g}$ sample was taken in a warring blender. The sample was homogenized with warring blender by adding $50 \mathrm{ml}$ distilled water. The homogenized solution was transferred into a $250 \mathrm{ml}$ volumetric flask and its volume was made up to the mark with distilled water and then centrifuged at $0^{\circ} \mathrm{C}$ for 20 minutes at a speed of $4000 \mathrm{rpm}$. The supernatant liquid was collected in the $250 \mathrm{ml}$ volumetric flask. This was the extract solution for the determination of ascorbic acid. 


\section{Ascorbic acid determination}

The ascorbic acid content was determined as per the procedure described by Pleshkov (1976). For estimating free ascorbic acid $10 \mathrm{ml}$ of prepared extract was taken in a conical flask. Five $\mathrm{ml} 5 \% \mathrm{KI}, 2 \mathrm{ml}$ of $2 \%$ starch solution, $2 \mathrm{ml}$ glacial acetic acid was added to the extract. Finally it was titrated with $0.001 \mathrm{~N} \mathrm{KIO}_{3}$ solution. Free ascorbic acid was quantified by using the following formula:

Ascorbic acid content $(\mathrm{mg} / 100 \mathrm{~g})=\frac{\mathrm{TFV}}{\mathrm{vW}} \times 100$.

Where,

$\mathrm{T}=$ Titrated volume of $\mathrm{KIO}_{3}(\mathrm{ml})$

$\mathrm{F}=0.088 \mathrm{mg}$ of ascorbic acid per $\mathrm{ml}$ of $0.001 \mathrm{~N} \mathrm{KIO}_{3}$

$\mathrm{V}=$ Total volume of sample extracted $(\mathrm{ml})$

$\mathrm{v}=$ Volume of the extract $(\mathrm{ml})$ taken for titration

$\mathrm{W}=$ Weight of the sample taken

\section{Estimation of $\beta$-carotene}

One gram of sample was crushed and mixed thoroughly with $10 \mathrm{ml}$ acetone: hexane (4:6) solution. This sample was centrifuged and optical density of the supernatant was measured by spectrophotometer (Model no. 200-20, Hitachi, Japan) at $663 \eta \mathrm{m}, 645 \eta \mathrm{m}, 505 \eta \mathrm{m}$ and $453 \eta \mathrm{m}$. Calculation was done by the following formula (Nagata et al., 1992).

$\beta$-Carotene $(\mathrm{mg} / 100 \mathrm{~g})=0.216\left(\mathrm{OD}_{663}\right)+0.452\left(\mathrm{OD}_{453}\right)-1.22\left(\mathrm{OD}_{645}\right)-0.304$ $\left(\mathrm{OD}_{505}\right)$

Where, bold figure indicates optical density.

\section{Total iron}

Dried plant materials were digested with concentrated $\mathrm{HNO}_{3}$ and $\mathrm{HClO}_{4}$ mixture as described by Piper (1966) for determination of total iron content. The instrument (Atomic Absorption Spectrophotometer. Model no. 170-30, Hitachi, Japan) was calibrated with standard solution of $\mathrm{Fe}$ and calibration curve was prepared by the series of standard solution. AAS readings of each standard solutions and sample extracts were recorded at wave length of $248.3 \mathrm{\eta m}$ for Fe.

$\mathrm{Fe}$ in plant $(\mathrm{ppm})=\mathrm{Fe}$ in the filtrate $(\mathrm{mg} / \mathrm{L}) \times 1000 \mathrm{ml} / 0.5 \mathrm{~g}$

\section{Total calcium}

Dried plant materials were digested with concentrated $\mathrm{HNO}_{3}$ and $\mathrm{HClO}_{4}$ mixture as described by Piper (1966) for determination of total calcium content. 
Total Ca $(\%)=(\mathrm{S}-\mathrm{B}) \times(1000 \mathrm{ml} / 10 \mathrm{ml}) \times(50 \mathrm{ml} / 0.5 \mathrm{~g}) \times 1 / 10^{4}$

Where,

$\mathrm{S}=$ Sample absorbance

$\mathrm{B}=$ Blank absorbance

\section{Total phosphorus}

Dried plant materials were digested with concentrated $\mathrm{HNO}_{3}$ and $\mathrm{HCIO}_{4}$ mixture as described by Piper (1966) for determination of total phosphorus content.

Total $\mathrm{P}(\%)=(\mathrm{S}-\mathrm{B}) \times(1000 \mathrm{ml} / 10 \mathrm{ml}) \times(50 \mathrm{ml} / 0.5 \mathrm{~g}) \times 1 / 10^{4}$

Where,

$\mathrm{S}=$ Sample absorbance

$\mathrm{B}=$ Blank absorbance

\section{Total potassium}

Dried plant materials were digested with concentrated $\mathrm{HNO}_{3}$ and $\mathrm{HClO}_{4}$ mixture as described by Piper (1966) for determination of total potassium content.

Total K $(\%)=(\mathrm{S}-\mathrm{B}) \times(1000 \mathrm{ml} / 10 \mathrm{ml}) \times(50 \mathrm{ml} / 0.5 \mathrm{~g}) \times 1 / 10^{4}$

Where,

$\mathrm{S}=$ Sample absorbance

$\mathrm{B}=$ Blank absorbance

\section{Statistical analysis}

The data of various parameters recorded in the experiment were compiled and statistically analyzed through partitioning the total variance with the help of computer MSTATC program. Analysis of variance was done according to Gomez and Gomez (1984). Means were separated using Duncan's Multiple Range Test (DMRT) at $1 \%$ or $5 \%$ level of probability.

\section{Results and Discussion}

\section{Water content}

The water content of curd was significantly influenced by different levels of $\mathrm{N}$ fertilizer (Table 1). The maximum water content $(92.08 \%)$ was recorded from the highest dose of $\mathrm{N}$ fertilizer $\mathrm{N}_{5}(200 \mathrm{~kg} \mathrm{~N} / \mathrm{ha})$ followed by $\mathrm{N}_{4}(91.72 \%)$, which was statistically identical to $\mathrm{N}_{3}(91.51 \%)$ and $\mathrm{N}_{2}(91.29 \%)$ whereas minimum water content $(90.62 \%)$ was recorded from $\mathrm{N}_{1}(0 \mathrm{~kg} \mathrm{~N} / \mathrm{ha})$. Similar results were reported by Candido et al. (2010) in case of cauliflower. 
The water content of curd was also significantly influenced by the different plant spacings (Table 2). The maximum water content $(91.58 \%)$ was recorded from the widest spacing $S_{1}(60 \mathrm{~cm} \times 60 \mathrm{~cm})$ which was statistically identical to $S_{2}$ $(91.46 \%)$ and minimum water content $(91.29 \%)$ was recorded from $\mathrm{S}_{3}(60 \mathrm{~cm} \mathrm{x}$ $30 \mathrm{~cm}$ ). Similar results were found by Waseem and Nadim (2001) in case of spinach.

Table 1. Effect of nitrogen levels on water content (\%) and dry matter content (\%) of broccoli.

\begin{tabular}{|c|c|c|}
\hline Levels of nitrogen & $\begin{array}{c}\text { Water content } \\
(\%)\end{array}$ & $\begin{array}{l}\text { Dry matter content } \\
(\%)\end{array}$ \\
\hline $\mathrm{N}_{1}(0)$ & $90.62 \mathrm{c}$ & $9.38 \mathrm{a}$ \\
\hline $\mathrm{N}_{2}(80)$ & $91.29 \mathrm{~b}$ & $8.71 \mathrm{~b}$ \\
\hline $\mathrm{N}_{3}(120)$ & $91.51 \mathrm{~b}$ & $8.49 \mathrm{~b}$ \\
\hline $\mathrm{N}_{4}(160)$ & $91.72 \mathrm{ab}$ & $8.28 \mathrm{bc}$ \\
\hline $\mathrm{N}_{5}(200)$ & $92.08 \mathrm{a}$ & $7.92 \mathrm{c}$ \\
\hline Level of significance & $* *$ & $* *$ \\
\hline $\mathrm{CV} \%$ & 1.39 & 4.2 \\
\hline
\end{tabular}

Means bearing same letter (s) in a column do not differ significantly at $1 \%$ level of probability by DMRT.

Table 2. Effect of plant spacing on water content (\%) and dry matter content (\%) of broccoli.

\begin{tabular}{c|c|c}
\hline Spacings & $\begin{array}{c}\text { Water content } \\
(\%)\end{array}$ & $\begin{array}{c}\text { Dry matter content } \\
(\%)\end{array}$ \\
\hline $\mathrm{S}_{1}(60 \times 60)$ & $91.58 \mathrm{a}$ & $8.42 \mathrm{~b}$ \\
$\mathrm{~S}_{2}(60 \times 45)$ & $91.46 \mathrm{ab}$ & $8.54 \mathrm{ab}$ \\
$\mathrm{S}_{3}(60 \times 30)$ & $91.29 \mathrm{~b}$ & $8.71 \mathrm{a}$ \\
\hline Level of significance & $*$ & $*$ \\
$\mathrm{CV} \%$ & 1.39 & 4.20 \\
\hline
\end{tabular}

Means bearing same letter (s) in a column do not differ significantly at 1 or $5 \%$ level of probability by DMRT.

The interaction effect of different levels of nitrogen and plant spacing on the water content in curd was found significant (Table 3). The highest water content $(92.36 \%)$ was recorded in $\mathrm{T}_{5}\left(\mathrm{~S}_{60 \times 60} \mathrm{~N}_{200}\right)$, which was statistically identical to all except $\mathrm{T}_{6}(91.33 \%), \mathrm{T}_{7}(90.90 \%), \mathrm{T}_{8}(91.27 \%), \mathrm{T}_{11}(90.46 \%), \mathrm{T}_{12}(91.28 \%), \mathrm{T}_{13}$ (91.40\%), $\mathrm{T}_{14}(91.40 \%)$ and $\mathrm{T}_{1}(90.08)$. The lowest water content $(90.08 \%)$ was found in $\mathrm{T}_{1}\left(\mathrm{~S}_{60 \times 60} \mathrm{~N}_{0}\right)$. 
Table 3. Interaction effect of spacing and nitrogen levels on water content (\%), dry matter content $(\%)$, ascorbic acid and $\beta$-carotene content of broccoli.

\begin{tabular}{|c|c|c|c|c|}
\hline $\begin{array}{l}\text { Treatment } \\
\text { combination } \\
(\mathrm{S} X \mathrm{~N})\end{array}$ & $\begin{array}{c}\text { Water content } \\
(\%)\end{array}$ & $\begin{array}{c}\text { Dry matter } \\
\text { content } \\
(\%)\end{array}$ & $\begin{array}{l}\text { Ascorbic acid } \\
(\mathrm{mg} / 100 \mathrm{~g})\end{array}$ & $\begin{array}{c}\beta- \\
\text { carotene(IU/100g) }\end{array}$ \\
\hline $\mathrm{T}_{1}\left(\mathrm{~S}_{60 \times 60} \mathrm{~N}_{0}\right)$ & $90.08 \mathrm{e}$ & $9.92 \mathrm{a}$ & $46.50 \mathrm{ab}$ & $50.67 \mathrm{a}$ \\
\hline $\mathrm{T}_{2}\left(\mathrm{~S}_{60 \times 60} \mathrm{~N}_{80}\right)$ & $91.68 \mathrm{abc}$ & 8.32 cde & $45.06 \mathrm{bc}$ & $45.67 \mathrm{c}$ \\
\hline $\mathrm{T}_{3}\left(\mathrm{~S}_{60 \times 60} \mathrm{~N}_{120}\right)$ & $91.88 \mathrm{ab}$ & $8.12 \mathrm{de}$ & $43.33 \mathrm{bcd}$ & $38.00 \mathrm{e}$ \\
\hline $\mathrm{T}_{4}\left(\mathrm{~S}_{60 \times 60} \mathrm{~N}_{160}\right)$ & $91.92 \mathrm{ab}$ & $8.08 \mathrm{de}$ & $34.34 \mathrm{gh}$ & $33.67 \mathrm{~g}$ \\
\hline $\mathrm{T}_{5}\left(\mathrm{~S}_{60 \times 60} \mathrm{~N}_{200}\right)$ & $92.36 \mathrm{a}$ & $7.64 \mathrm{e}$ & $30.79 \mathrm{~h}$ & $32.00 \mathrm{i}$ \\
\hline $\mathrm{T}_{6}\left(\mathrm{~S}_{60 \times 45} \mathrm{~N}_{0}\right)$ & $91.33 \mathrm{bcd}$ & $8.67 \mathrm{bcd}$ & $44.50 \mathrm{bc}$ & $47.00 \mathrm{~b}$ \\
\hline $\mathrm{T}_{7}\left(\mathrm{~S}_{60 \times 45} \mathrm{~N}_{80}\right)$ & $90.90 \mathrm{cde}$ & $9.09 \mathrm{abc}$ & $43.13 \mathrm{bcd}$ & $42.00 \mathrm{~d}$ \\
\hline $\mathrm{T}_{8}\left(\mathrm{~S}_{60 \times 45} \mathrm{~N}_{120}\right)$ & $91.27 \mathrm{bcd}$ & $8.73 \mathrm{bcd}$ & $42.19 \mathrm{bcd}$ & $35.67 \mathrm{f}$ \\
\hline $\mathrm{T}_{9}\left(\mathrm{~S}_{60 \times 45} \mathrm{~N}_{160}\right)$ & $91.84 \mathrm{ab}$ & $8.16 \mathrm{de}$ & $36.01 \mathrm{fg}$ & $32.00 \mathrm{i}$ \\
\hline $\mathrm{T}_{10}\left(\mathrm{~S}_{60 \times 45} \mathrm{~N}_{200}\right)$ & $91.95 \mathrm{ab}$ & $8.05 \mathrm{de}$ & $30.14 \mathrm{~h}$ & $30.33 \mathrm{k}$ \\
\hline $\mathrm{T}_{11}\left(\mathrm{~S}_{60 \times 30} \mathrm{~N}_{0}\right)$ & $90.46 \mathrm{de}$ & $9.54 \mathrm{ab}$ & $50.38 \mathrm{a}$ & $45.67 \mathrm{c}$ \\
\hline $\mathrm{T}_{12}\left(\mathrm{~S}_{60 \times 30} \mathrm{~N}_{80}\right)$ & $91.28 \mathrm{bcd}$ & $8.72 \mathrm{bcd}$ & 40.97 cde & $42.00 \mathrm{~d}$ \\
\hline $\mathrm{T}_{13}\left(\mathrm{~S}_{60 \times 30} \mathrm{~N}_{120}\right)$ & $91.40 \mathrm{bc}$ & $8.60 \mathrm{~cd}$ & $39.38 \mathrm{def}$ & $32.67 \mathrm{~h}$ \\
\hline $\mathrm{T}_{14}\left(\mathrm{~S}_{60 \times 30} \mathrm{~N}_{160}\right)$ & $91.40 \mathrm{bc}$ & $8.60 \mathrm{~cd}$ & $37.17 \mathrm{efg}$ & $31.00 \mathrm{j}$ \\
\hline $\mathrm{T}_{15}\left(\mathrm{~S}_{60 \times 30} \mathrm{~N}_{200}\right)$ & $91.92 \mathrm{ab}$ & $8.08 \mathrm{de}$ & $32.68 \mathrm{gh}$ & 30.011 \\
\hline $\begin{array}{c}\text { Level of } \\
\text { significance }\end{array}$ & $* *$ & $* *$ & $*$ & $* *$ \\
\hline $\mathrm{CV}(\%)$ & 1.39 & 4.20 & 6.61 & 5.51 \\
\hline
\end{tabular}

Means bearing same letter (s) in a column do not differ significantly at 1 or $5 \%$ level of probability by DMRT.

\section{Dry matter}

The dry matter content of curd was significantly influenced by the different levels of $\mathrm{N}$ fertilizer (Table 1). The maximum dry matter $(9.38 \%)$ was recorded from $\mathrm{N}_{1}(0 \mathrm{~kg} \mathrm{~N} / \mathrm{ha})$ followed by $\mathrm{N}_{2}(8.71 \%), \mathrm{N}_{3}(8.49 \%)$, and $\mathrm{N}_{4}(8.28 \%)$, whereas the lowest dry matter content $(7.92 \%)$ was recorded from the highest level of nitrogen. Rembialkowska et al. (2003) reported that plants grown without nitrogen fertilizer contained more dry matter compared to plants grown with nitrogen fertilizer, which are in conformity with the present findings.

The dry matter content of curd was also significantly influenced by the different spacings (Table 2). The maximum dry matter content $(8.71 \%$ ) was recorded from the closest spacing $S_{3}(60 \mathrm{~cm} \times 30 \mathrm{~cm})$, which was followed by $S_{2}$ 
$(8.54 \%)$ treatment and the minimum dry matter content $(8.42 \%)$ was recorded in $\mathrm{S}_{1}(60 \mathrm{~cm} \times 60 \mathrm{~cm})$.

The interaction effect of different levels of $\mathrm{N}$ fertilizers and plant spacings on the dry matter content was significant (Table 3). The highest dry matter content $(9.92 \%)$ was recorded in $\mathrm{T}_{1}\left(\mathrm{~S}_{60 \times 60} \mathrm{~N}_{0}\right)$, which was statistically identical to $\mathrm{T}_{7}$ (9.10\%) and $\mathrm{T}_{11}$ (9.54). The lowest dry matter content (7.64\%) was found in $\mathrm{T}_{5}$ $\left(\mathrm{S}_{60 \times 60} \mathrm{~N}_{200}\right)$.

\section{Ascorbic acid}

Variation in ascorbic acid due to the nitrogen level was statistically significant (Fig. 1). It ranged from 31.20 to $47.13 \mathrm{mg} / 100 \mathrm{~g}$. The highest ascorbic acid content $(47.13 \mathrm{mg} / 100 \mathrm{~g})$ was recorded in $\mathrm{N}_{1}(0 \mathrm{~kg} \mathrm{~N} / \mathrm{ha})$ and the lowest $(31.20$ $\mathrm{mg} / 100 \mathrm{~g})$ was in $\mathrm{N}_{5}(200 \mathrm{~kg} \mathrm{~N} / \mathrm{ha})$. In a study Karitonas (2001) stated that increased level of $\mathrm{N}$ supply slightly reduced the vitamin $\mathrm{C}$ content from 83 to 73 $\mathrm{mg} / 100 \mathrm{~g}$, which was more or less similar to the present findings.

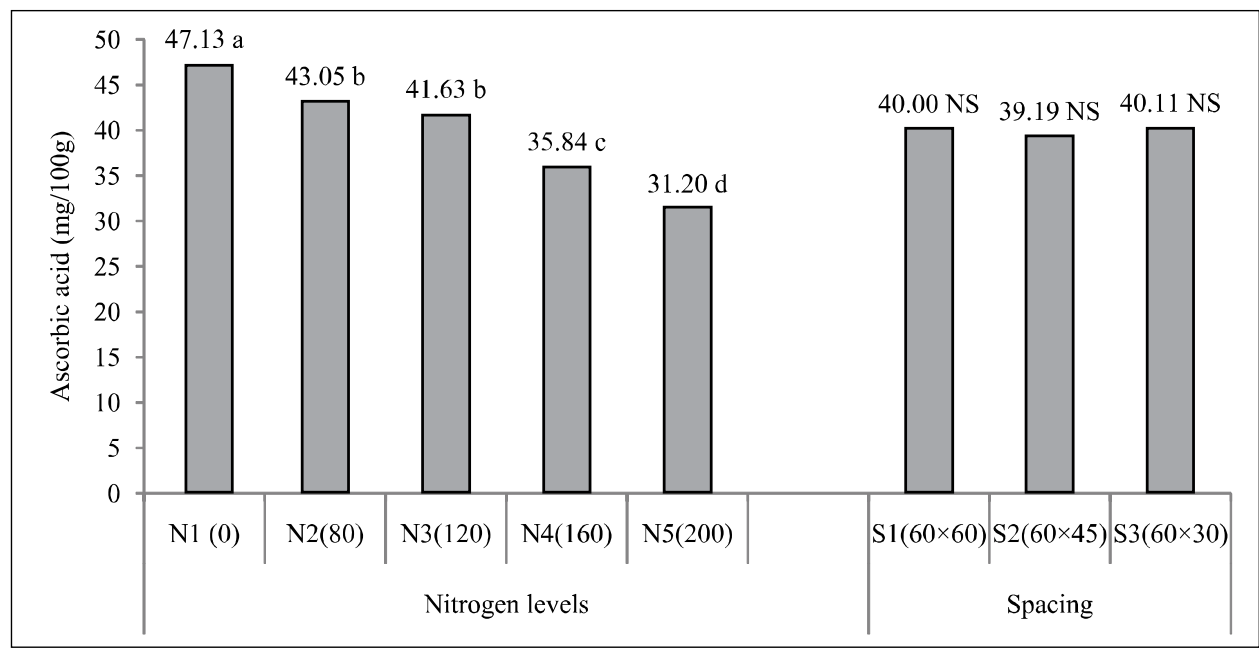

Fig. 1. Effect of nitrogen levels and plant spacing on ascorbic acid content.

The ascorbic acid content of curd did not vary significantly by the different spacings (Fig. 1). Numerically it ranged from $39.19 \mathrm{mg} / 100 \mathrm{~g}$ to $40.11 \mathrm{mg} / 100 \mathrm{~g}$.

The interaction effect of different levels of $\mathrm{N}$ fertilizers and plant spacings on the ascorbic acid content in curd was found significant (Table 3). The highest ascorbic acid content $(50.38 \mathrm{mg} / 100 \mathrm{~g})$ was recorded in $\mathrm{T}_{11}\left(\mathrm{~S}_{60 \times 30} \mathrm{~N}_{0}\right)$, which was statistically identical to $\mathrm{T}_{1}(46.50 \mathrm{mg} / 100 \mathrm{~g})$ and the lowest ascorbic acid content (30.14 mg/100g) was found in $\mathrm{T}_{10}\left(\mathrm{~S}_{60 \times 45} \mathrm{~N}_{200}\right)$. This was might be due to the highest nitrogen dose which reduced dry matter content resulting in less ascorbic acid. 


\section{$\beta$-carotene}

Significant variations in the amount of $\beta$-carotene were found due to influence of nitrogen levels. It varied from 47.78 to $30.78 \mathrm{IU} / 100 \mathrm{~g}$ (Fig. 2). The highest $\beta$ carotene content $(47.78 \mathrm{IU} / 100 \mathrm{~g})$ was recorded in $\mathrm{N}_{1}(0 \mathrm{~kg} \mathrm{~N} / \mathrm{ha})$, which was followed by $\mathrm{N}_{2}(43.22 \mathrm{IU} / 100 \mathrm{~g}), \mathrm{N}_{3}(35.44 \mathrm{IU} / 100 \mathrm{~g})$ and $\mathrm{N}_{4}(32.22 \mathrm{IU} / 100 \mathrm{~g})$. The lowest $(30.78 \mathrm{IU} / 100 \mathrm{~g})$ was in $\mathrm{N}_{5}(200 \mathrm{~kg} \mathrm{~N} / \mathrm{ha})$. Rembialkowska et al. (2003) reported that plants grown without fertilizer contained higher amount of $\beta$ carotene than that grown with inorganic fertilizer.

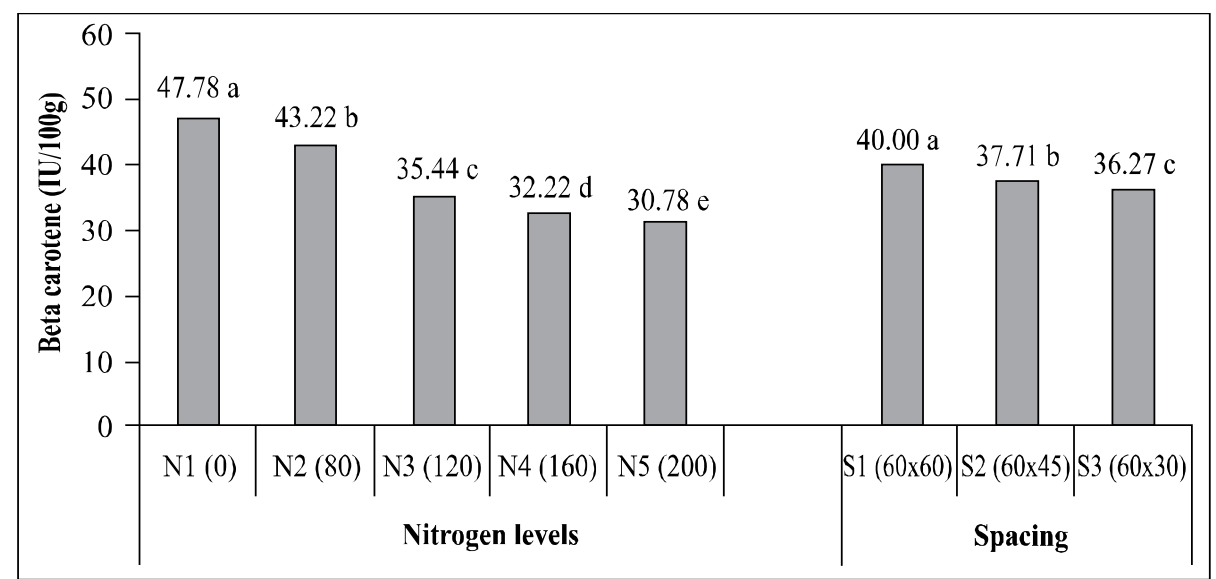

Fig. 2. Effect of nitrogen levels and plant spacing on $\beta$-carotene content.

The $\beta$-carotene content of curd was also significantly influenced by the different plant spacings (Fig. 2). The maximum $\beta$-carotene content (40.00 IU/100g) was recorded from the widest spacing $S_{1}(60 \mathrm{~cm} \times 60 \mathrm{~cm})$, which was followed by $S_{2}(37.40 \mathrm{IU} / 100 \mathrm{~g})$ treatment and minimum $\beta$-carotene content (36.27 IU/100g) was recorded from $\mathrm{S}_{3}(60 \mathrm{~cm} \times 30 \mathrm{~cm})$.

Different levels of $\mathrm{N}$ fertilizer and plant spacing had significant influence on the $\beta$-carotene content in curd (Table 3). The highest $\beta$-carotene content (50.67 IU/100g) was recorded in the treatment combination $\mathrm{T}_{1}\left(\mathrm{~S}_{60 \times 60} \mathrm{~N}_{0}\right)$, which was followed by $\mathrm{T}_{6}(47.00 \mathrm{IU} / 100 \mathrm{~g}), \mathrm{T}_{2}(45.67 \mathrm{IU} / 100 \mathrm{~g}), \mathrm{T}_{7}(42.00 \mathrm{IU} / 100 \mathrm{~g}), \mathrm{T}_{3}$ (38.00 IU/100g) $\mathrm{T}_{8}(35.67 \mathrm{IU} / 100 \mathrm{~g}) \mathrm{T}_{4}(33.67 \mathrm{IU} / 100 \mathrm{~g})$ and $\mathrm{T}_{13}(32.67 \mathrm{IU} / 100 \mathrm{~g})$. The lowest $\beta$-carotene content $(30.01 \mathrm{IU} / 100 \mathrm{~g})$ was found in $\mathrm{T}_{15}\left(\mathrm{~S}_{60 \times 30} \mathrm{~N}_{200}\right)$.

\section{Iron}

Differences in iron content (Fig. 3) in broccoli curd were found significant. Iron content was maximum (154.896 ppm) in $\mathrm{N}_{5}(200 \mathrm{~kg} \mathrm{~N} / \mathrm{ha})$ and minimum (88.031 ppm) in $\mathrm{N}_{1}(0 \mathrm{~kg} \mathrm{~N} / \mathrm{ha})$.

In case of plant spacing a significant result was found in iron content (Fig. 3). The maximum iron content $(131.410 \mathrm{ppm})$ was recorded from the medium 
spacing $S_{2}(60 \mathrm{~cm} \times 45 \mathrm{~cm})$, which was followed by $S_{3}(120.304 \mathrm{ppm})$ and minimum iron content (106.210 ppm) was recorded from widest spacing $S_{1}$ (60 $\mathrm{cm} \times 60 \mathrm{~cm}$ ).

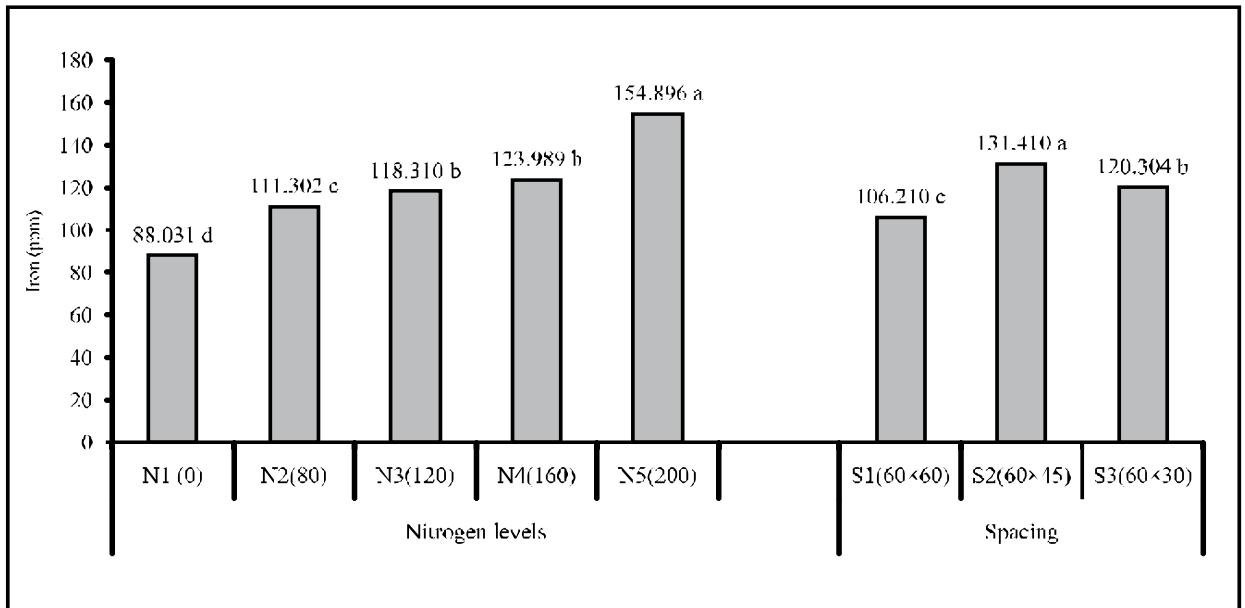

Fig. 3. Effect of nitrogen levels and plant spacing on iron content.

Iron content varied due to the interaction effect of different levels of $\mathrm{N}$ fertilizer and plant spacing (Table 4). The highest iron content (161.001 ppm) was recorded in $\mathrm{T}_{10}\left(\mathrm{~S}_{60 \times 45} \mathrm{~N}_{200}\right)$, which was statistically identical to $\mathrm{T}_{5}(159.002$ $\mathrm{ppm})$. The lowest iron content (72.201 ppm) was found in $\mathrm{T}_{1}\left(\mathrm{~S}_{60 \times 60} \mathrm{~N}_{200}\right)$. Sharma and Chandra (2004) reported similar results.

\section{Calcium}

Significant variation in calcium content (Fig. 4) was observed due to influence different nitrogen levels. The highest $(0.548 \%)$ calcium content was found in $\mathrm{N}_{1}$ ( $0 \mathrm{~kg} \mathrm{~N} / \mathrm{ha})$, which was followed by $\mathrm{N}_{2}(0.474 \%)$ and $\mathrm{N}_{3}(0.429 \%)$ and the lowest $(0.391 \%)$ calcium was found in $\mathrm{N}_{5}(200 \mathrm{~kg} \mathrm{~N} / \mathrm{ha})$.

In case of plant spacings, an insignificant result was found in calcium content (Fig. 4). Apparently the maximum calcium content $(0.459 \%)$ was recorded from the moderate spacing $S_{2}(60 \mathrm{~cm} \times 45 \mathrm{~cm})$, which was followed by $S_{3}(0.457 \%)$ and minimum calcium content $(0.447 \%)$ was recorded from the widest spacing $S_{1}$ $(60 \mathrm{~cm} \times 60 \mathrm{~cm})$.

The interaction effect of different levels of $\mathrm{N}$ fertilizers and plant spacings on the calcium content was found significant (Table 4). The highest calcium content $(0.556 \%)$ was recorded in the treatment combination of $\mathrm{T}_{1}\left(\mathrm{~S}_{60 \times 60} \mathrm{~N}_{0}\right)$, which was statistically identical to treatment $\mathrm{T}_{11}(0.550 \%)$ and $\mathrm{T}_{6}(0.536 \%)$. The lowest calcium content $(0.366 \%)$ was found in $\mathrm{T}_{5}\left(\mathrm{~S}_{60 \times 60} \mathrm{~N}_{200}\right)$. 


\section{Phosphorus}

There was a significant variation in phosphorus content in curd (Fig. 5) due to different nitrogen levels. It ranged from $0.161 \%$ to $0.201 \%$. The maximum phosphorus content was recorded in $\mathrm{N}_{5}\left(0.201 \%\right.$.) followed by $\mathrm{N}_{4}\left(0.196 \%\right.$.), $\mathrm{N}_{3}$ $\left(0.186 \%\right.$.), $\mathrm{N}_{2}\left(0.176 \%\right.$.). The lowest $(0.161 \%)$ was in $\mathrm{N}_{1}(0 \mathrm{~kg} \mathrm{~N} / \mathrm{ha})$.

Table 4. Interaction effect of spacing and nitrogen levels on iron $(\mathrm{Fe})$, calcium $(\mathrm{Ca})$, phosphorus $(\mathrm{P})$ and potassium $(\mathrm{K})$ content in broccoli.

\begin{tabular}{|c|c|c|c|c|}
\hline $\begin{array}{c}\text { Treatment } \\
\text { combination } \\
(\mathrm{S} X \mathrm{~N})\end{array}$ & $\begin{array}{c}\text { Iron }(\mathrm{Fe}) \\
(\mathrm{ppm})\end{array}$ & $\begin{array}{c}\text { Calcium }(\mathrm{Ca}) \\
(\%)\end{array}$ & $\begin{array}{c}\text { Phosphorus }(\mathrm{P}) \\
(\%)\end{array}$ & $\begin{array}{c}\text { Potassium }(\mathrm{K}) \\
(\%)\end{array}$ \\
\hline $\mathrm{T}_{1}\left(\mathrm{~S}_{60 \times 60} \mathrm{~N}_{0}\right)$ & $72.201 \mathrm{i}$ & $0.556 \mathrm{a}$ & $0.166 \mathrm{~g}$ & $0.836 \mathrm{~d}$ \\
\hline $\mathrm{T}_{2}\left(\mathrm{~S}_{60 \times 60} \mathrm{~N}_{80}\right)$ & $97.732 \mathrm{~h}$ & $0.446 \mathrm{~cd}$ & $0.190 \mathrm{c}$ & $0.846 \mathrm{~b}$ \\
\hline $\mathrm{T}_{3}\left(\mathrm{~S}_{60 \times 60} \mathrm{~N}_{120}\right)$ & $99.150 \mathrm{~h}$ & $0.420 \mathrm{df}$ & $0.190 \mathrm{c}$ & $0.820 \mathrm{f}$ \\
\hline $\mathrm{T}_{4}\left(\mathrm{~S}_{60 \times 60} \mathrm{~N}_{160}\right)$ & $103.001 \mathrm{gh}$ & $0.446 \mathrm{~cd}$ & $0.210 \mathrm{a}$ & $0.820 \mathrm{f}$ \\
\hline $\mathrm{T}_{5}\left(\mathrm{~S}_{60 \times 60} \mathrm{~N}_{200}\right)$ & $159.002 \mathrm{a}$ & $0.366 \mathrm{e}$ & $0.186 \mathrm{~d}$ & $0.836 \mathrm{~d}$ \\
\hline $\mathrm{T}_{6}\left(\mathrm{~S}_{60 \times 45} \mathrm{~N}_{0}\right)$ & $99.404 \mathrm{~h}$ & $0.536 \mathrm{ab}$ & $0.156 \mathrm{i}$ & $0.816 \mathrm{~g}$ \\
\hline $\mathrm{T}_{7}\left(\mathrm{~S}_{60 \times 45} \mathrm{~N}_{80}\right)$ & $123.601 \mathrm{def}$ & $0.490 \mathrm{bc}$ & $0.166 \mathrm{~g}$ & $0.840 \mathrm{c}$ \\
\hline $\mathrm{T}_{8}\left(\mathrm{~S}_{60 \times 45} \mathrm{~N}_{120}\right)$ & $134.804 \mathrm{bcd}$ & $0.446 \mathrm{~cd}$ & $0.180 \mathrm{e}$ & $0.850 \mathrm{a}$ \\
\hline $\mathrm{T}_{9}\left(\mathrm{~S}_{60 \times 45} \mathrm{~N}_{160}\right)$ & $138.003 \mathrm{bc}$ & $0.420 \mathrm{de}$ & $0.190 \mathrm{c}$ & $0.816 \mathrm{~g}$ \\
\hline $\mathrm{T}_{10}\left(\mathrm{~S}_{60 \times 45} \mathrm{~N}_{200}\right)$ & $161.001 \mathrm{a}$ & $0.400 \mathrm{de}$ & $0.206 \mathrm{~b}$ & $0.830 \mathrm{e}$ \\
\hline $\mathrm{T}_{11}\left(\mathrm{~S}_{60 \times 30} \mathrm{~N}_{0}\right)$ & $92.502 \mathrm{~h}$ & $0.550 \mathrm{a}$ & $0.160 \mathrm{~h}$ & $0.816 \mathrm{~g}$ \\
\hline $\mathrm{T}_{12}\left(\mathrm{~S}_{60 \times 30} \mathrm{~N}_{80}\right)$ & $112.605 \mathrm{fg}$ & $0.486 \mathrm{bc}$ & $0.170 \mathrm{f}$ & $0.820 \mathrm{f}$ \\
\hline $\mathrm{T}_{13}\left(\mathrm{~S}_{60 \times 30} \mathrm{~N}_{120}\right)$ & 120.903 ef & $0.420 \mathrm{de}$ & $0.186 \mathrm{~d}$ & $0.836 \mathrm{~d}$ \\
\hline $\mathrm{T}_{14}\left(\mathrm{~S}_{60 \times 30} \mathrm{~N}_{160}\right)$ & 130.802 cde & $0.420 \mathrm{de}$ & $0.186 \mathrm{~d}$ & $0.816 \mathrm{~g}$ \\
\hline $\mathrm{T}_{15}\left(\mathrm{~S}_{60 \times 30} \mathrm{~N}_{200}\right)$ & $144.702 \mathrm{~b}$ & $0.406 \mathrm{de}$ & $0.210 \mathrm{a}$ & $0.846 \mathrm{~b}$ \\
\hline $\begin{array}{c}\text { Level of } \\
\text { significance }\end{array}$ & $* *$ & $*$ & $*$ & $*$ \\
\hline $\mathrm{CV}(\%)$ & 4.47 & 6.93 & 4.31 & 1.76 \\
\hline
\end{tabular}

Means bearing same letter(s) in a column do not differ significantly at 1 or $5 \%$ level of probability by DMRT.

In case of plant spacing, a significant result was found in phosphorus content (Fig. 5). The maximum phosphorus content $(0.189 \%)$ was recorded from the widest spacing $S_{1}(60 \mathrm{~cm} \times 60 \mathrm{~cm})$, which was followed by $\mathrm{S}_{3}(0.183 \%)$ treatment and minimum phosphorus content $(0.180 \%)$ was recorded from medium spacing $\mathrm{S}_{2}(60 \mathrm{~cm} \times 45 \mathrm{~cm})$.

Different levels of $\mathrm{N}$ fertilizer and plant spacing had significant effect on the phosphorus content in curd (Table 4). The highest phosphorus content $(0.210 \%)$ 
was recorded in $\mathrm{T}_{4}\left(\mathrm{~S}_{60 \times 60} \mathrm{~N}_{160}\right)$ and $\mathrm{T}_{15}\left(\mathrm{~S}_{60 \times 30} \mathrm{~N}_{200}\right)$. The lowest phosphorus content $(0.160 \%)$ was found in the treatment combination $\mathrm{T}_{11}\left(\mathrm{~S}_{60 \times 30} \mathrm{~N}_{0}\right)$.

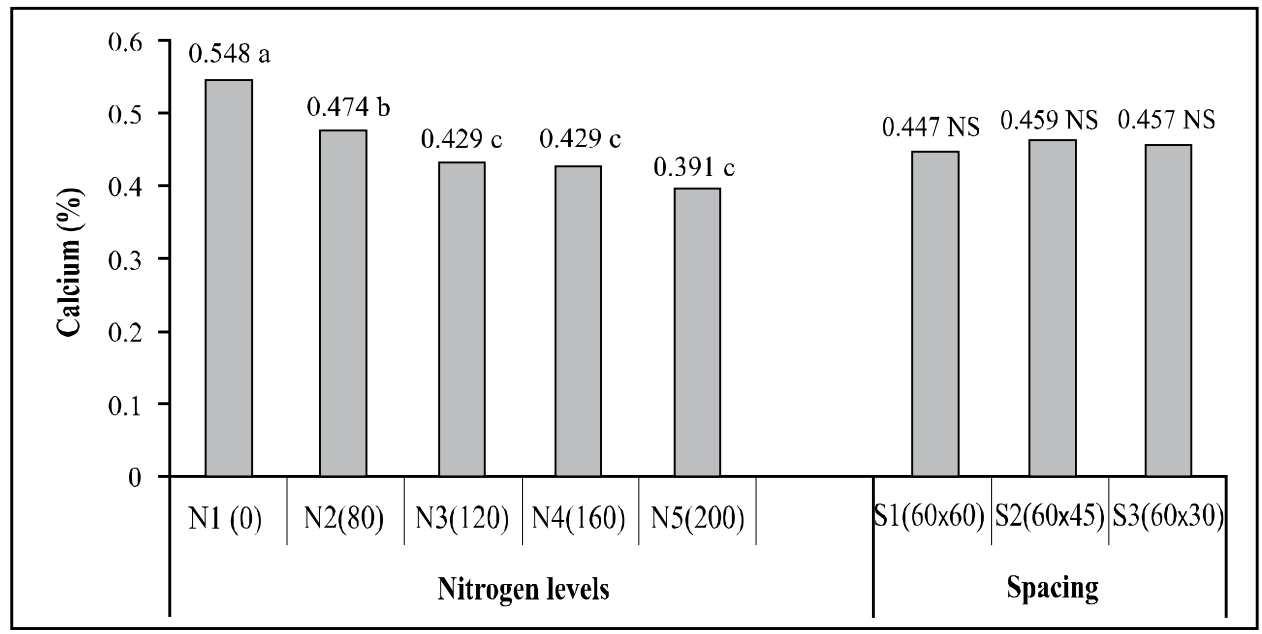

Fig. 4. Effect of nitrogen levels and plant spacing on calcium content.

\section{Potassium}

Potassium content was also significantly influenced by the nitrogen levels (Fig. 6). The highest amount of potassium $(0.838 \%)$ was recorded in $\mathrm{N}_{5}(200 \mathrm{~kg} \mathrm{~N} / \mathrm{ha})$ closely followed by that of $\mathrm{N}_{3}(0.836 \%)$ and $\mathrm{N}_{2}(0.836 \%)$. The lowest potassium content $(0.818 \%)$ was observed in $\mathrm{N}_{4}(160 \mathrm{~kg} \mathrm{~N} / \mathrm{ha})$.

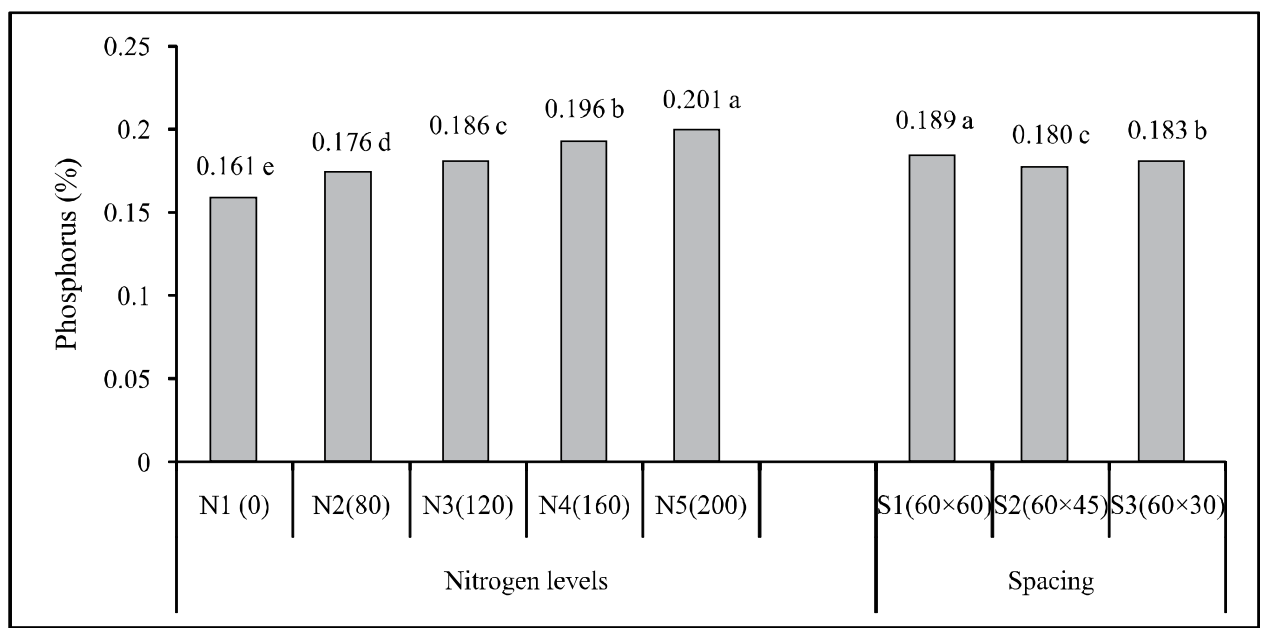

Fig. 5. Effect of nitrogen levels and plant spacing on phosphorus content.

In case of plant spacings, a significant result was found in potassium content (Fig. 6). The maximum potassium content $(0.883 \%)$ was recorded from the widest spacing $S_{1}(60 \mathrm{~cm} \times 60 \mathrm{~cm})$, which was followed by $S_{2}(0.831 \%)$ and 
minimum potassium content $(0.823 \%)$ was recorded from the closest spacing $\mathrm{S}_{3}$ $(60 \mathrm{~cm} \times 30 \mathrm{~cm})$.

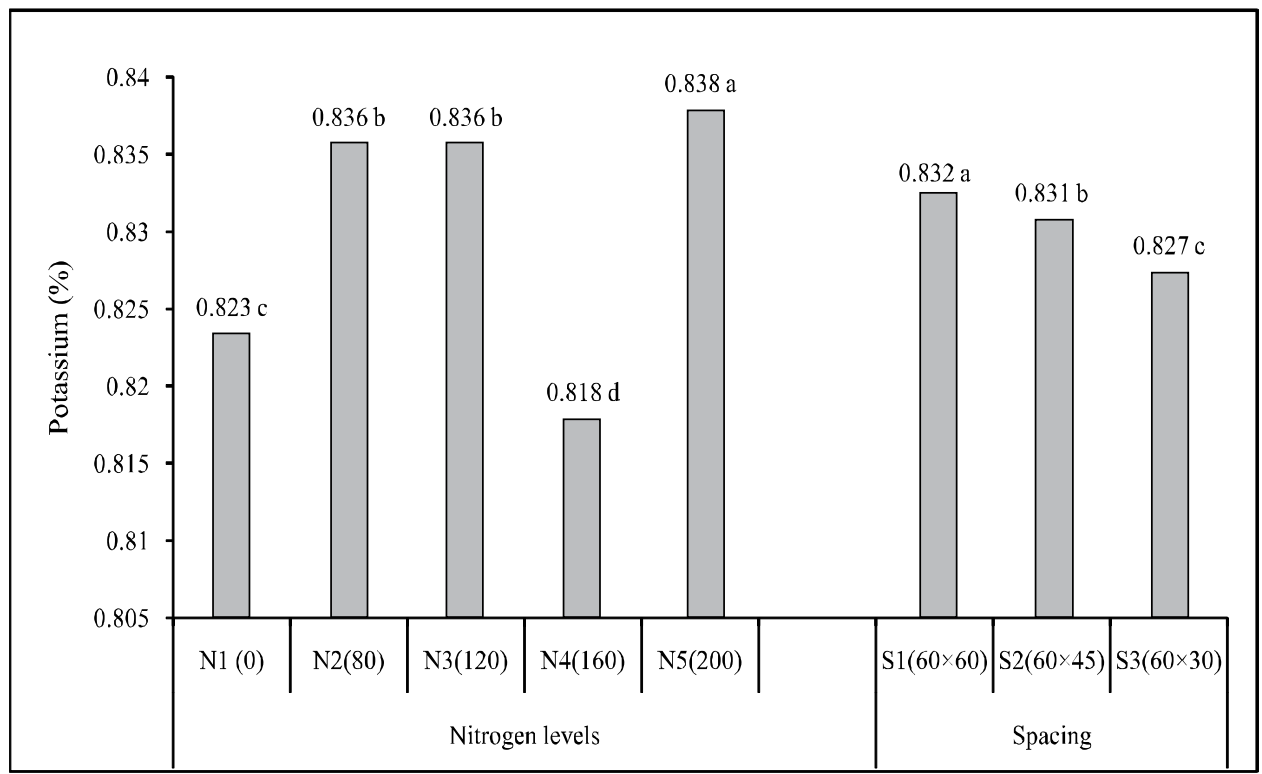

Fig. 6. Effect of nitrogen levels and plant spacing on content of potassium.

The interaction effect of different levels of $\mathrm{N}$ fertilizers and plant spacings on the potassium content was significant (Table 4). The highest potassium content $(0.850 \%)$ was recorded in $\mathrm{T}_{8}\left(\mathrm{~S}_{60 \times 45} \mathrm{~N}_{120}\right)$ and the lowest potassium content $(0.816 \%)$ was found in $\mathrm{T}_{6}, \mathrm{~T}_{9}, \mathrm{~T}_{11}$, and $\mathrm{T}_{14}$.

\section{Conclusion}

On the basis of the results of the present study, it can be concluded that the content of ascorbic acid, $\beta$-carotene, and calcium were maximum in broccoli produced in absence of inorganic nitrogen whereas iron, phosphorus, and potassium were maximum in broccoli produced with the highest dose of nitrogen $(200 \mathrm{~kg} / \mathrm{ha})$.

\section{Acknowledgments}

We are grateful to the Ministry of Science, Information and Communication Technology, Govt. of the People's Republic of Bangladesh for their financial support.

\section{References}

Anonymous. 2010. Year Book of Agricultural Statistics of Bangladesh, Bangladesh Bureau of Statistics, Statistics Division, Ministry of Planning, Govt. of Peoples' Republic of Bangladesh, Dhaka, Pp. 37-41. 
Candido V, F. Galgano, V. Miccolis, I. Cossidente, F. Favati. 2010. Genotype and storage effects on quality traits of cauliflower of the "Valle dell'Ofanto" (Italy). Italus-Hortus. 17(2): 107-109.

Gomez, K. A., A. A. Gomez. 1984. Statistical procedure for Agriculture Research. John Wily \& Sons. N. Y., Pp. 20-215.

Karitonas, R. 2001. Effect of nitrogen supply on yield and quality of broccoli. Plantnutrition food security and sustainability of agro-ecosystems through basic and applied research. Fourteenth International Plant Nutrition Colloquium, Hannover, Germany, Pp. 298-299.

Lisiewska, Z, W. Kmiecik. 1969. Effects of level of nitrogen fertilizers, processing conditions and period of storage of frozen broccoli and cauliflower on vitamin C retention. Food Chemistry 57(2):267-270.

Nagata, M., K. Dan and I. Yamashita. 1992. Simple methods for simultaneous determination of chlorophyll and carotenoids in tomato. J. Japan. Soc. Hort. Sci. 61(2): 685-687.

Nieuwhof, M. 1969. Cole Crops, Botany, Cultivation and Utilization. Leonard. Book Co., England, Pp. 100-120.

Nonnecke, I. L. 1989. Vegetable Production. Vein Nostrand Reinhold, New York.

Piper, C. S. 1966. Soil and Plant Analysis. Hans Publishers, Bombay, (Reprint): 368-392.

Pleshkov, B. P. 1976. Practical works on plant biochemistry. Moscow, Kolos, Pp. 236238.

Prasad, S., U. Kumar. 1999. Principles of Horticulture. Agrobotanica, 4E 176. J, N. Vyas Nagar, India, P. 6.

Rembialkowska, E., M. M. Tijskens, H. M. Vollebregt. 2003. Organic farming as a system to provide better vegetable quality. Proceedings of the International Conference on Quality in Chains, an Integrated View on Fruit and Vegetable Quality, Wageningen, Netherlands. Volume 2. Acta. Horticulturae. 2: 604, 473-479.

Roy, A. 2011. Consumption of vegetables and fruits and its importance. The Daily Star, 10 August, P.11.

Sazzad, M. 1996. Optimizing fertilizer requirement for broccoli cultivation. M.S. Thesis. Dept. Soil Science. Bangababdhu Sheik Mujibur Rahman Agricultural University, Gazipur, Bangladesh.

Sharma, A., A. Chandra. 2004. Effect of plant density and nitrogen levels on physicochemical parameters of cauliflower. Haryana J. Horticultural Sci. 2004; 33(1/2): 148149.

Thompson. H. C., W. C. Kelly. 1985. Vegetable Crops. Fifth edition, McGraw Hill. Book Co. New York, Toronto, London, P. 307.

Waseem, K., A. Nadeem. 2001. Enhancement of spinach production by varying sowing dates, row spacing and frequency of cuttings. Online J. Bio. Sci. Asian Network for Scientific Information 1(10): 902-904. 